\title{
Significant Effect of Project Based Learning Video on Students' Listening Skill in Pandemic Situation
}

\author{
Ni Wayan Febiyanti*, Putu Kerti Nitiasih², Luh Gd Rahayu Budiarta ${ }^{3}$, Ni Luh Putu \\ Era Adnyayanti 4
}

1,2,3,4 English Education Department, Ganesha University of Education, Singaraja, Indonesia

\section{A R T I C L E I N F O}

\section{Article history:}

Received May 20, 2021

Revised May 31, 2021

Accepted July 23, 2021

Available online August 25, 2021

Kata Kunci:

PBL, Kemampuan Mendengarkan Video Pembelajaran

Keywords:

PBL, Listening Skill, Learning Video

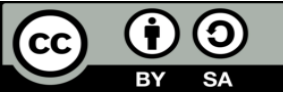

This is an open access article under the CC BY-SA license.

Copyright (C) 2021 by Author. Published by Universitas Pendidikan Ganesha.

\begin{abstract}
A B S T R A K
Mendengarkan merupakan salah satu keterampilan berbahasa yang penting dipelajari oleh siswa. Akan tetapi, guru sangat sulit mengajar kemampuan tersebut pada pembelajaran di masa pandemic Covid-19. Guru memerlukan teknik mengajar yang inovatif, salah satunya dengan menggunakan media video. Penelitian ini bertujuan untuk menginvestigasi dampak dari penggunaan video pembelajaran berbasis projek terhadap kemampuan pemahaman mendengarkan pada siswa. Populasi pada penelitian ini melibatkan siswa kelas 4 sekolah dasar. Sampel pada penelitian ini menggunakan 40 siswa kelas 4 dari satu kelas intak yang dipilih dengan tujuan tertentu. Penelitian ini mencakup penelitian kuantitatif dengan desain one group pretest-posttest. Instrumen pengumpulan data pada studi ini menggunakan test pemahaman mendengarkan dan rubrik penilaian pemahaman mendengarkan. Data yang dikumpulkan dianalisis menggunakan analisis deskriptif dan inferensial statistik. Dari hasil penelitian didapatkan bahwa nilai mean kelompok pada posttest adalah 86.85 yang mana lebih besar dibandingkan dengan nilai mean pada saat pretest yaitu 75.75. Standar deviasi pada pretest juga menunjukkan nilai sebesar 5.678 dan standar deviasi pada posttest yaitu 3.180. Dari hasil inferensial statistik analisis menunjukkan bahwa nilai Sig. (2-tailed) yaitu .000. dan lebih rendah dibandingkan Sig. level (.05). Oleh karena itu, dapat disimpulkan bahwa terdapat dampak signifikan pada penggunaan video pembelajaran berbasis project pada pemahaman mendengarkan siswa selama pandemic covid-19.
\end{abstract}

\section{A B S T R A C T}

Listening is one of the most important language skills to be learned by students. However, it is very difficult for teachers to teach these skills in learning during the Covid-19 pandemic. Teachers need innovative teaching techniques, one of which is using video media. This study aims to investigate the impact of using project-based learning videos on students' listening comprehension skills. The population in this study involved 4th grade elementary school students. The sample in this study used 40 grade 4 students from one intact class that were selected with a specific purpose. This research includes quantitative research with one group pretest-posttest design. The data collection instrument in this study used a listening comprehension test and a listening comprehension assessment rubric. The data collected were analyzed using descriptive and inferential statistical analysis. From the results of the study, it was found that the mean value of the group at the posttest was 86.85 which was greater than the mean value at the pretest, which was 75.75. The standard deviation on the pretest also shows a value of 5,678 and the standard deviation on the posttest is 3,180. From the results of statistical inferential analysis shows that the value of Sig. (2-tailed) is .000. and lower than Sig. levels (.05). Therefore, it can be concluded that there is a significant impact on the use of project-based learning videos on students' listening comprehension during the covid-19 pandemic.

\section{INTRODUCTION}

People need language as a tool of communication. They must master four language skills in order to build the success of communication (Gonulal, 2020; Lestari, 2019). Although listening skills is a part of receptive skills, this skill is very important for language skill. From those skills, listening becomes one part of important skills (Erdogan, 2019; Shafwati et al., 2021). Listening is an active process which students need to be considered in order to ease communication between the hearer and speaker (Babayigit, 2019; Demir \& Tavil, 2021; Douglas et al., 2017; Karkera \& Chamundeshawari, 2018). Listening takes a significant role which needs $40-50 \%$ part in a communication rather than the other language skills. Listening refers to an ability in conveying and comprehending what others are saying (Rizkan et al., 2020). Thus, it simply stated that listening refers to an active process which involves ability in conveying and understanding the words or massages in order to build communication. Listening comprehension skill is a 
vital English skill which becomes a key in the success of effective communication (Ahmadi, 2016; Faramarzi et al., 2019; Sutrisno, 2020). Listening comprehension skill involved the process of comprehending, determining, and identifying what the speaker says (Atiyah \& Izzah, 2019). Listening comprehension can be defined as a mental process of relating sounds, vocabulary, grammartical structures and background knowledges between the speakers and listeners (Vandergrift, 1999). Thus, listening comprehension skill can be defined as a skill which employs of process in understanding the meaning of conversations through the influences of vocabulary, grammartical structures and background knowledges between speakers and listeners.

In fact, it is difficult to teach listening skill. Even students feel challenging to acquire listening skills (M. Putri \& Sinaga, 2020). Teachers need an innovative teaching technique to make sure that all students understand what they heard. Neverthless, in this COVID-19 pandemic, many sectors have experienced changes, one of which is in the education sector (Liu, 2020; Novianti \& Garzia, 2020). Some standards that has recommended, such as social distancing and physical distancing make several activities change, specifically learning activities at school. In the Covid19 pandemic, learning takes place online, which is very different from what was usually done in the classroom (Balkist \& Agustiani, 2020; Diningrat et al., 2020). Distance learning or using online systems have provided solutions for schools that are starting to implement the School from Home (SFH) system (Rasmitadila et al., 2020; Zaharah et al., 2020). In this, SFH considers the health and safety of students, educators, education staff, and the community. Thus, during this pandemic situation, teachers should change their learning strategy or technique. They should prepare interesting materials or technique to increase students' motivation even in online learning environment. It is because when the teaching materials are not interesting for students, they will learn nothing (Harmer, 2003).

Authentic materials can be one of the choices techniques to teach English skill including listening. Authentic material can be defined as materials, which proposed for teaching including written text, audio recordings, and direct communication or video (Gardner \& Miller, 1999; Nunan, 1999). As what mentioned previously, authentic materials consist of visual, audio and printed materials. It is supported by statement who mentioned that there are several kinds of authentic material i.e. authentic listening viewing materials, authentic visual materials, and printed materials (Gebhard, 2006). The example of authentic printed materials are articles, newspaper, lyrics, restaurant menu, and street signs. Further, authentic audio/visual materials can be seen in quiz show, video, movies, radio dramas etc. Authentic materials in the form of visual materials involve slide, photographs, pictures, etc (Boyaci \& Guner, 2018).

Some experts have conducted several previous studies about the effect of authentic materials on students' language learning skill (Badri \& Salehi, 2017; Gunduz et al., 2017; Polat \& Eriști, 2019; K. H. Putri et al., 2018). A study of forty female and male of University students in Iran which proved the significant impact on oral authentic materials in improving students' listening comprehension skill and developing motivation (Badri \& Salehi, 2017). In the same line, a quasi-experimental study that was participated by 8 turkish and 22 cypriot pre advanced English students (Gunduz et al., 2017). The data collection through questionnaire were analysed by independent sample test and one-way ANOVA. The results find that authentic materials seem to be useful in real situations, and able to improve students' listening skills. Other study that focused on investigating the effect of implementing authentic listening materials and selfregulation on students' listening ability of tenth graders in SMAN 1 VII (K. H. Putri et al., 2018). Since the data were analysed through t-test and two-way ANOVA, the findings show that 1) authentic materials give better impact towards students' listening ability, 2) authentic materials enhance students' listening ability who has a good self-regulation, and 3) there is correlation between authentic materials on self-regulation to enhance students' listening ability. Other study investigated the effect of authentic video materials on EFL learners' listening skill and listening anxiety through experiemental studies with pretest-posttest true experimental design. The data collection that gathered from 100 randomly selected students revealed that authentic video materials highly effective in developing English listening skill and reducing students' listening anxiety (Polat \& Erişti, 2019). It is because authentic video materials reflect real language and communication samples.

Video becomes an example of authentic materials because it shows real life communication and not intended to use as teaching. Video as an authentic material can be integrated in teaching listening skills and support to develop listening comprehension skill of learners (Harmer, 2001). It is because, video offers more useful than the traditional media (Kim, 2015). Video is also a powerful teaching media since students learn many things from what they watch (Muslem et al., 2017). However, teachers should consider a good video and appropriate with the learning materials and objectives (Obagah \& Brisibe, 2017; Yacoob \& Saad, 2020). While most of the aforementioned of previous studies focused on investigating the effect of video on students listening skill in a university students and junior high school students, some of them tend to use different method of data analysis, setting, and topics of the learning 
materials (Aboudahr \& Farag, 2020; Rahmadani, 2018; Rizkan et al., 2020; Sutrisno, 2020). However, from the review of previous studies, it can prove that the use of video as learning tool or materials give a significant impact on listening comprehension skill. The video used can trigger students' motivation, reduce anxiety, and provide them a real life situation with authentic materials. Since the previous empirical reviews have been revealed the positive significant impact of using video towards students' listening skill, thus, it is urgent to conduct this study about the effect of project based learning video towards young learners' listening skill. In this recent study, the researcher chose project based learning video as an authentic material for teaching young learners. The reason of choosing video as a technique in teaching listening because young learners tend to learn and understand the language by video. Besides, video provides visualization and colorful that makes them more interested in the learning topics. As mentioned in theory of the level of cognitive development, children aged 7-12 years have the main characteristics of holistic, beautiful, playful, and concrete thinking skill (Kristiantari, 2015).

Thus, it required the teacher preparing the media that can provide contextual and meaningful learning. In addition, project based learning video as a treatment in the experimental group provides authentic materials which lead students to interested more in the learning activity. Therefore, the researcher interested in investigating the effect of project based learning video on students' listening comprehension skill in pandemic situation. The aim of the study was to investigate whether using project based learning video gives a positive effect on students' listening comprehension skill during this pandemic Covid-19 or not. The novelty of this recent study can be seen in terms of the setting, learning topics, population and sample, and method of data analysis that were used during the research. The setting was employed young learners while the topics were clothes and activites in the classroom.

\section{METHOD}

The study was conducted in SD Negeri 2 Alasangker, Buleleng Regency, Bali Province. The population involved fourth graders while the sample was 40 students in fourth graders in academic year 2020/2021. The sample was chosen purposively by the recomendation from the teacher. Meanwhile, project based learning video was measured as the learning medium by considering the requirement of authentic materials and supported by previous studies. The research applied quantitative which used a pre-experimental study. Brown (2015) proposes quantitative research denotes to a research that employs numbers as the data and use statistics analysis to measure the data. The study adopted one group pretestposttest design. Since the design was one group pretest-posttest, this study only involved one intact group which were given pretest and posttest (Gay et al., 2012). The students were given pretest and posttest in the form of listening comprehension test. There are 25 questions in the test which were created based on two basic competencies on syllabus for fourth graders namely clothes and activities in the classroom. In order to know the details information related to reseach design, it can be seen in the Table 1.

Table 1. Research Design

\begin{tabular}{cccc}
\hline Experimental & Pretest & Treatment & Post-test \\
\cline { 2 - 4 } Group & 0 & $X$ & 0 \\
\hline
\end{tabular}

Based on Table 1, it can be stated that the effect of the treatments can be measured by doing comparison on listening score during the pretest and posttest. The treatments can be revealed as giving the significant effect on students' listening comprehension skill if the Sig.value of Sig. (2-tailed) was lower than the Sig. Level (0.05). In addition, the data collection was analysed inferentially through pair sample test if the data were normally distributed. When the Sig.value of normality test aided by Kolmogorov Smirnov was higher than .05, it can be stated that the data were normally distributed. Since this study was a pre-experimental study, it involved independent and dependent variable (Cresswell, 2012). Independent variable is defined as a variable which cause something. Meanwhile, dependent variable means as a variable which get influence by other variable. The independent of the study was problem based learning video while the dependent variable was students' listening skill. The data collection was gathered through listening test. The instruments were listening comprehension test and listening rubric. Listening comprehension test was used to measure the pretest and posttest. The instrument involved 25 of multiple choice questions related to clothes and activities in the classroom. Due to the administered of pretest and posttest, listening comprehension test was created based on two basic compentencies such as Clothes and Activities in the classroom. The grid of listening comprehension test can be seen in Table 2 . 
Table 2. Instrument Grid of Listening Comprehension Test

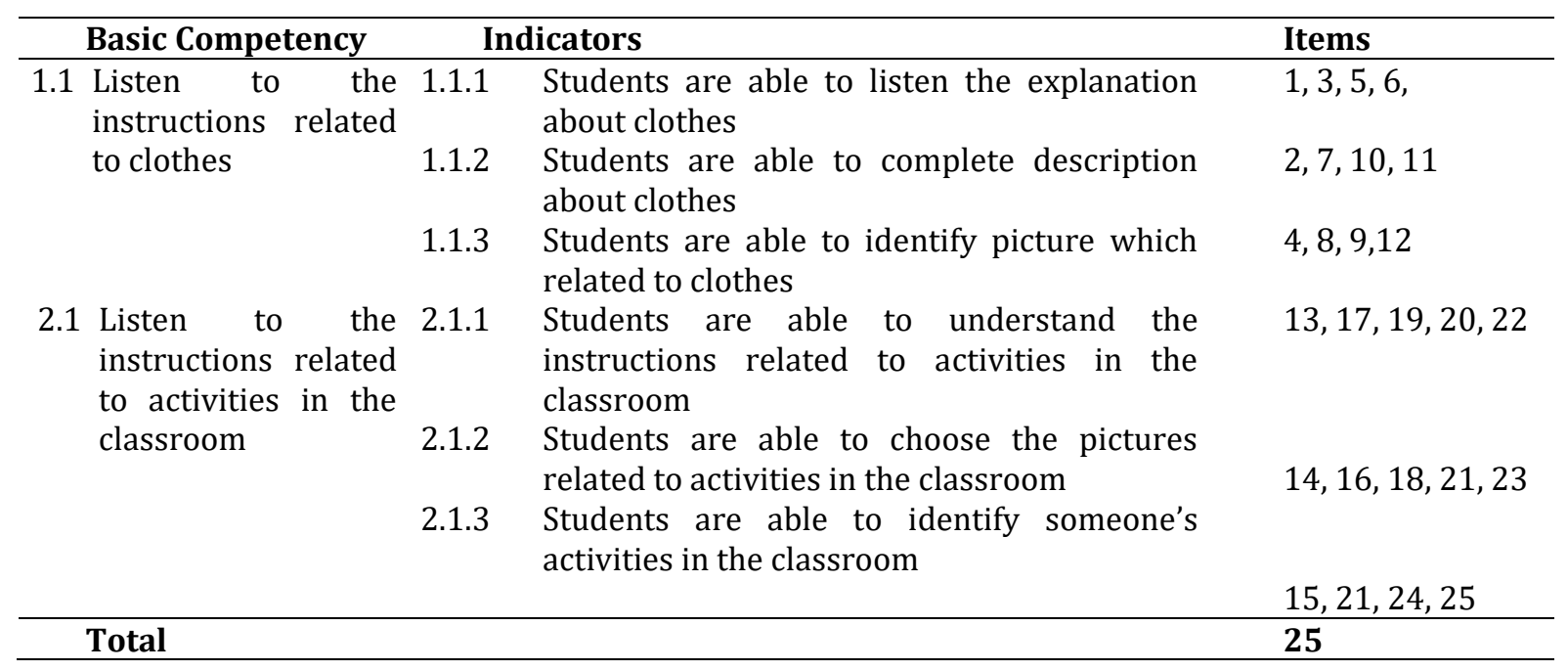

The pre-test and post-test instruments had been measured through content validity and reliability. It is because the categories of a valid instrument were valid and reliable. The content validity was measured by two expert judges. Then, the instruments analysed using Gregory' table to see the results whether the instruments were valid or not. The content validity process showed the results that pre-test and post-test instruments was 0.90 which can be classified as a high. Meanwhile, the listening rubric became the guidance in deciding the score of the pretest or posttest. The research procedures can be divided into several steps i.e. 1) determining the sample of the research, 2) administering pretest, 3) giving treatments under the integration of video as a learning media, 4) administering posttest, 5) analysing the normality data through Kolmogorov Smirnov, 6) analysing the data through descriptive statistics and inferential data, 7) checking the effect size, and 8) concluding the reserch findings. The treatments consisted of four meetings with 2 Basic Competencies namely Clothes and Activities in the classroom. Since the treatments, the students were taught using project based learning video with two topics that is clothes and activities in the classroom. The data were analysed by IBM SPSS Statistics version 24 whereas the effect size was measured by Effect Size Calculator. The value of cohen d score can be classified into small, medium, and large effect. The criteria of classification on effect size calculator can be seen in Table 3.

Table 3. Criteria of Cohens D

\begin{tabular}{cc}
\hline Cohen's d score & Interpretation \\
\hline $0.8 \leq d \leq 2.0$ & Large \\
$0.5 \leq d<0.8$ & Medium \\
$0.2 \leq d<0.5$ & Small \\
\hline
\end{tabular}

\section{RESULT AND DISCUSSION}

\section{Result}

In this pre-experimental study, a group was treated by the use of project based learning as a learning media in teaching students' listening comprehension skill. In order to know the difference between the mean of pretest and the mean of the posttest, the data collection was analysed through descriptive statistic analysis. The result can be ilustrated in Figure 1. Figure 1 shows that the standard deviation of pretest was 5.678 which was higher than the standard deviation of posttest 3.810 . Hence, the group pretest mean was 75.75 and the posttest mean of 86.85. It means that the posttest mean was higher than the pretest mean. It can be concluded that there is significant difference between the posttest mean and the pretest mean. After analysing the data descriptively, the data collection was analysed inferentially to measure the effect of using project based learning video towards students' listening comprehension skill. The treatments gave a positive significant effect on students' listening comprehension skill if the significance value of Sig. (2-tailed) was lower than the Sig. Level of .05. However, it is necessary to measure the normality test through Kolmogorov Smirnov aided by IBM SPSS Statistics 24. If the normality test has been fulfilled the requirement of inferential test, the data can be analysed inferentially to test the 
hypothesis. Based on data analysis, it reveals that the sig.value of pretest was .131 while that of posttest was .118. The data can be stated as normally distributed because both pretest and posttest significance value was higher than .05 which was fulfilled the requirement of normality test. Then, the inferential statistics can be measured since the data were normally distributed.

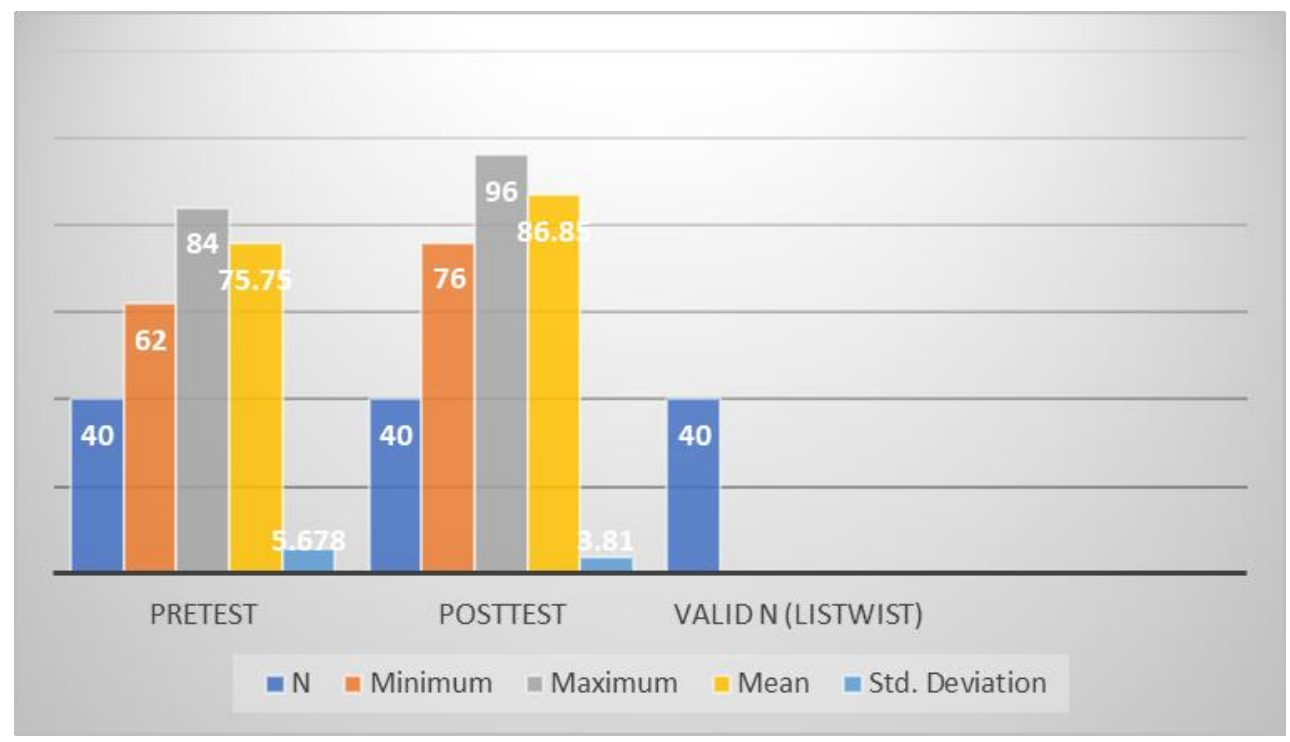

Figure 1. Descriptive Statistic Analysis

Inferential statistic used pair sample test because considering the use of single group in this research. The data were analysed through comparing between the posttest mean and pretest mean aided by IBM SPSS Statistics 24. The results of pair sample test can be seen in Table 4.

Table 4. The Results of Hypothesis Testing

\begin{tabular}{|c|c|c|c|c|c|c|c|c|c|}
\hline & & \multicolumn{5}{|c|}{ Paired Differences } & \multirow[b]{3}{*}{$\mathbf{t}$} & \multirow[b]{3}{*}{ df } & \multirow{3}{*}{$\begin{array}{l}\text { Sig. (2- } \\
\text { tailed) }\end{array}$} \\
\hline & & \multirow[b]{2}{*}{ Mean } & \multirow{2}{*}{$\begin{array}{c}\text { Std. } \\
\text { Deviation }\end{array}$} & \multirow{2}{*}{$\begin{array}{l}\text { Std. } \\
\text { Error } \\
\text { Mean }\end{array}$} & \multicolumn{2}{|c|}{$\begin{array}{l}95 \% \text { Confidence } \\
\text { Interval of the } \\
\text { Difference }\end{array}$} & & & \\
\hline & & & & & Lower & Upper & & & \\
\hline Pair 1 & $\begin{array}{l}\text { pretest - } \\
\text { posttest }\end{array}$ & 11.1000 & 7.18902 & 1.13668 & 8.8008 & 13.3991 & 9.765 & 39 & .000 \\
\hline
\end{tabular}

The results of Table 5 show that the standard deviation was 7.189 while the mean was 11.1000 . In addition, the result of Significance value of Sig. (2-tailed) was .000. It indicated that the value of Sig. (2tailed) was lower than the Sig. level of .05. It can be inferred that Ho "There is no significant effect of using project based learning video on students' listening comprehension skill during pandemic situation" was rejected. It means that there is a positive significant effect of using project based learning video on students' listening comprehension skill in pandemic situation.

\section{Discussion}

As mentioned previously that the results of data analysis were tested through effect size calculator in order to measure how big the effect of using project based learning video on students' listening comprehension skill. Based on analysis data, it finds that the Cohen's d was 2.41 while the effect size $r$ of 0.76 . As the Cohen's d score was higher than 2.0, it can be categorized as a large effect based on Becker's criterias. It can be concluded that the use of project based learning videos offer large significant effect to enhance listening comprehension skill of fourth grade students in SD Negeri 2 Alasangker during this pandemic Covid-19. As Figure 1 reveals that, the group pretest mean was 75.75 which was lower than the posttest mean of 86.85 . Hence, the standard deviation of pretest was 5.678 which was higher than the standard deviation of posttest 3.810. It can be inferred that there is significant difference between the pretest mean and the posttest mean. Meanwhile the pair sample test finds out that the sig. value of Sig. (2tailed) was .000 which was lower than the Sig. level of .05. It implied that there is a positive significant effect of project-based learning videos on students' listening comprehension skill in pandemic situation. 
The results of the research was sthrengthened by previous study who reveals that authentic materials, one of which is video can increase students' language learning including listening comprehension skill (Harmer, 2001). Since the setting of the learning environment used online setting due to the pandemic situation, those results also prove and strengthen who argue that video can be applied in online learning environment (Obagah \& Brisibe, 2017).

The significant difference between group pretest mean and group posttest mean is attributed by several factors. First, it may have caused by video which is a part of authentic materials. Authentic audio/visual materials can be seen in quiz show, video, movies, radio drams and etc (Boyaci \& Guner, 2018). It means video is a part of authentic materials. In this experimental study, the group was taught under problem-based learning videos which divided into two topics namely Clothes and Activities in the classroom. The video involved the examples of clothes and activities in the classroom and were given during the treatments. Further, the students have a real examples and real experiences in learning language skills which ease them to understand the language or vocabularies. It is in agreement with the statement that authentic materials provide real examples for students of how to communicate in the real life situations, and lead students to focuses more on the language skills rather than other skills (Maroko, 2010). Second factor was that video offer scene or images that shows expressions and attract students' attention. It leads students to keep focusing on the learning materials in the video. Authentic video materials also offer a wider and richer of real experssions context, increase students' motivation and provide students a meaningful experience rather than non-authentic materials (Gilmore, 2011). Third, video as a learning media/material in this research may attributed in creating effective learning environment. As we know that, teaching and learning activities was shifted from face-to-face learning into online learning environment. So, problem-based learning videos can be an effective way to teach listening skill without ignoring the health protocal by the government. Teachers easily to deliver the materials towards the students. Since authentic video materials includes audiovisual aspects leading to the development of students' listening skills because authentic materials deliver students an opportunity to pay more attention on learning activities and create effective learning environment offer important opportunities for students to focus their attention on learning activities (Gunbay \& Mede, 2011).

Based on the findings of inferential analysis, the null hypothesis was rejected. It implied that the use of project based learning videos give a positive impact on student's listening comprehension skill in pandemic situation. The reason for why the project-based learning video offers significant impact towards students' listening skill is that video provides them to watch scenes, images, and listening the audio. Watching and listening to the audio at the same time leads students to pay more attention on the video given. It is in agreement statement who mentioned several advantages of using video in teaching language skill in the classroom. Integrating video materials in teaching learning activities increase students' motivation to learn the language since it can help them to expose wide of variety situations in real life (Mirvan, 2013). Previous study have strengthened this statement by revealing that video is a powerful teaching media for learning because learners can get information through what they are watching (Prabumulih, 2019). Video as a learning media is able to enhance student 'vocabulary, student's feeling, motivation, and classroom atmosphere (Prabumulih, 2019). In the same line, other study have revealed several advantages of video as a learning tool in learning and teaching activities i.e. 1) video provides joyful materials; 2) video can be an effective way for studying body language; 3) video improves students' confidence; 4) video can visualize the messages clearly; 5) video signifies technology-based learning, and 6) video can offer extra dimension of learning experience (Harmer, 2003). Those advantages may have attributed as the factors of the significant impact of project based learning video on students' listening comprehension skill at SD Negeri 2 Alasangker.

The results of effect size inferred as a large effect may also influenced by visualization of the video. As previously mentioned that young learners' characteristics are beautiful, and like to concrete things. They also tend to more interested in colorful things and authentic things rather than abstract. It may attribute on the student's ability in comprehending the listening materials and improve their listening skill. Young learners also familier with the use of technology (Dong, Cao \& Li, 2020). Since the setting was online learning environment and the learning material was administered through projectbased learning video, it may lead and increase students' motivatiton to listen the materials on videos. The results are also strengthened by study who found that video as an online learning materials is suitable for teaching and learning during this pandemic Covid-19 (Yacoob \& Saad, 2020). It can be the fact that the large effect occurs because the effectiveness of using video in online environment during this pandemic Covid-19.

Besides, the research findings was in agreement of several previous studies (Rizkan et al. 2018; Rahmadani, 2018; Sutrisno, 2020). Therefore, it could be concluded that there is significant effect of using project-based learning video on fourth graders' listening comprehension skill in pandemic situation. The 
effect can be revealed as a large effect since the results of Cohen's $d$ was higher than 2.00 as mentioned in the table criterias. Hence, problem-based learning videos can be inserted as an authentic material for teaching young learners specifically in teaching listening comprehension skill. The results of the study implied that using video specifically project-based learning video, can enhance students' listening skill. Since the results already prove that the use of project-based learning video is effective to improve listening skill, teachers can apply this teaching technique in online learning environment. However, this technique was limited to teach for young learners since the setting of the research used elementary school. Thus, it is very important for other researcher to investigate the effect of using project-based learning video on students' listening skill in the context of face-to-face learning or in other level of education.

\section{CONCLUSION}

Based on the descriptive analysis, it clearly implied that there is significant difference between the posttest group mean and the group's pretest mean while the significance value was lower than the significance level. It indicated that there is a positive significant effect of using project based learning video on students listening skill in pandemic situation. The significant effect of using video may attributed by the effective authentic materials, visualization, attractive, and fun for young learners. However, english teachers need to consider in choosing appropriate videos related to the learning materials because young learners' characteristics tend to be more complex than adult learners. It can be recommended some suggestions towards English teachers, material developers and other researchers. English teachers may add project based learning video in the listening activity so that students are easily to understand the materials and improve their listening comprehension skill. Material developers can develop meaningful and creative videos related to listening or other English skills. They are also suggested to add video as a learning technique in teaching listening skill. Since this research focused on young learners and used one of elementary school as the setting, other researchers may recommended to do other reasearch which focused on other English skills with other sample, setting, and research design. The future researchers can conduct a study which focuses more on the development of learning video in a creative design for young learners.

\section{REFERENCES}

Aboudahr, S., \& Farag, M. (2020). The Effect of Using Youtube to Increase the Level of Listening Skills among Non-Native Students of Arabic Speakers in Malaysian Universities. Education Quarterly Reviews, 3(2), 207-219. https://doi.org/10.31014/ajr.1993.03.02.133.

Ahmadi, S. M. (2016). The Importance of Listening Comprehension in Language Learning. International Journal of Research in English Education, 1(1), 7-10. www.ijreeonline.com.

Atiyah, F., \& Izzah, L. (2019). A Comparative Study on the Effectiveness of Using Direct and Audiovisual Methods for Enhancing Students Listening Comprehension. English Language in Focus (ELIF), 2(1), 1-12. https://doi.org/10.24853/elif.2.1.9-

Babayigit, O. (2019). Sixth Grade Students' Listening Comprehension of the Story Text. International Journal of Educational Methodology, 5(1), 35-42. https://doi.org/10.12973/ijem.5.1.35.

Badri, L., \& Salehi, M. (2017). The Effect of Oral Authentic Materials on Iranian EFL Learners' Motivation and Listening Comprehension Ability. International Journal of Instruction, 6(2), 312-322. https://jte.sru.ac.ir/article_730.html .

Balkist, P. S., \& Agustiani, N. (2020). Responses of Students with Special Needs to Online Mathematics Leaning during Pandemic. Journal of Physics: Conference Series, 1657(1). https://doi.org/10.1088/1742-6596/1657/1/012031.

Boyaci, S. D. B., \& Guner, M. (2018). The Impact of Authentic Material Use on Development of the Reading Comprehension, Writing Skills, and Motivation in Language Course. International Journal of Instruction, 11(2), 351-368. http://www.e-iji.net/dosyalar/iji_2018_2_24.pdf.

Cresswell, J. W. (2012). Educational Research. Pearson.

Demir, M. D., \& Tavil, Z. M. (2021). The Effect of Technology-Based Materials on Vocational High School Students' Listening Skill. Journal of Language and Linguistic Studies, 17(1), 448-457. https://www.jlls.org/index.php/jlls/article/view/2134.

Diningrat, S. W. M., Nindya, M. A., \& Salwa, S. (2020). Emergency Online Teaching: Early Childhood Education Lecturers' Perception of Barrier and Pedagogical Competency. Jurnal Cakrawala Pendidikan, 39(3), 705-719. https://doi.org/10.21831/cp.v39i3.32304.

Douglas, S. N., Nordquist, E., Kammes, R., \& Gerde, H. (2017). Online Parent Training to Support Children 
with Complex Communication Needs. Infants and Young Children, 30(4), 288-303. https://doi.org/10.1097/IYC.0000000000000101.

Erdogan, V. (2019). Integrating 4C Skills of 21st Century into 4 Language Skills in EFL Classes Vacide Erdoğan. International Journal of Education and Research, 7(11), 113-124.

Faramarzi, S., Tabrizi, H. H., \& Chalak, A. (2019). The Effect of Vodcasting Tasks on EFL Listening Comprehension Progress in an Online Program. International Journal of Instruction, 12(1), 12631280. https://doi.org/10.29333/iji.2019.12181a.

Gardner, D., \& Miller, L. (1999). Establishing Self-Access: From Theory to Practice. Cambridge University Press

Gay, I. R., Mills, E. G., \& Airasian, P. W. (2012). Research Method: Competencies for Analysis and Applications. Pearson Education Inc.

Gebhard, J. G. (2006). Teaching English as a Foreign or Second Language. A Self Development and Methodology Guide (2nd ed.). The University of Michigan Press.

Gilmore, A. (2011). I Prefer Not Text: Developing Japanese Learners' Communicative Competence with Authentic Materials. Language Learning, 61(3), 786-819. https://doi.org/10.1111/j.14679922.2011.00634.x.

Gonulal, T. (2020). Improoving Listening Skills with Extensive Listening Using Podcasts and Vodcasts. International Journal of Contemporary Educational Research, 7(1), 311-320. https: //files.eric.ed.gov/fulltext/EJ1262212.pdf.

Gunbay, E. B., \& Mede, E. (2011). Implementing Authentic Materials through Critical Friends Group (CFG): A Case from Turkey. The Qualitative Report, 22(11), 3055-3074. https://doi.org/10.46743/2160$3715 / 2017.2744$.

Gunduz, N., Ozcan, D., \& Uzunboylu, H. (2017). The Influence of Authentic Materials on the Students Listening Ability in EFL Classes. ENSAYOS. Revista de La Facultad de Educación de Albacete, 32(2), 135-146. https://www.researchgate.net/publication/330662072/.

Harmer, J. (2001). The Practice of English Language Teaching (3rd ed.). Longman Pearson Education Limited.

Harmer, J. (2003). The Practice of English Language Teaching. Pearson Education Limited.

Karkera, S., \& Chamundeshawari, C. (2018). Youtube: A Teaching Tool to Improve Listening Skills. International Journal of Creative Research Thoughts, 6(2), 1311-1316. https: //www.ijcrt.org/papers/IJCRT1813041.pdf.

Kim, H.-S. (2015). Using Authentic Videos to Improve EFL Students' Listening Comprehension. International Journal of Contents, 11(4), 15-24. https://doi.org/10.5392/ijoc.2015.11.4.015.

Kristiantari, M. R. (2015). Analisis Kesiapan Guru Sekolah Dasar dalam Mengimplementasikan Pembelajaran Tematik Integratif Menyongsong Kurikulum 2013. JPI (Jurnal Pendidikan Indonesia), 3(2). https://doi.org/10.23887/jpi-undiksha.v3i2.4462.

Lestari, J. A. (2019). The Use of Youtube Vlog to Improve the Students' Listening Skill of MTS Samarinda. Tarbiyah Wa Ta'lim: Jurnal Penelitian Pendidikan \& Pembelajaran, 6(1), 35-45. https://journal.iain-samarinda.ac.id/index.php/Tarbiyawat/article/download/2041/943.

Liu, L. (2020). Sustainable Covid-19 Mitigation: Wuhan Lockdowns, Health Inequities, and Patient Evacuation. International Journal of Health Policy and Management, 9(10), 415 - 418. https: //doi.org/10.34172/ijhpm.2020.63.

Maroko, G. M. (2010). The Authentic Materials Approach in the Teaching of Functional Writing in the Classroom. The New Decade and (2nd) FL Teaching. The Initial Phase Rudolf Reinelt Research Laboratory EU Matsuyama, 71 - 87. http://web.iec.ehime-u.ac.jp/reinelt/raineruto2/5 Geoffrey M Maroko.pdf.

Mirvan, X. (2013). The Advantages of Using Films to Enhance Student's Reading Skills in the EFL Classroom. Journal of Education and Practice, 4(13), 62-66. https://www.iiste.org/Journals/index.php/JEP/article/view/6775.

Muslem, A., Mustafa, F., Usman, B., \& Rahman, A. (2017). The Application of Video Clips with Small Group and Individual Activities to Improve Young Learners' Speaking Performance. Teaching English with Technology, 17(4), 25-37. https://www.ceeol.com/search/article-detail?id=579130.

Novianti, R., \& Garzia, M. (2020). Parental Engagement in Children's Online Learning during Covid-19 Pandemic. Journal of Teaching and Learning in Elementary Education (JTLEE), 3(2), 117. https://doi.org/10.33578/jtlee.v3i2.7845.

Nunan, D. (1999). Second Language Teaching and Learning. Heinle and Heinle Publishers. https://eric.ed.gov/?id=ED441344.

Obagah, R. R., \& Brisibe, W. G. (2017). The Effectiveness of Instructional Videos in Enhancing Learning Experience of Architecture Students in Design and Drawing Courses: A Case Study of Rivers State 
University, Port. Harcourt. International Journal of Education and Research, 5(11), 33-46. https: //www.ijern.com/journal/2017/November-2017/04.pdf.

Polat, M., \& Erişti, B. (2019). The Effects of Authentic Video Materials on Foreign Language Listening Skill Development and Listening Anxiety at Different Levels of English Proficiency. International Journal of Contemporary Educational Research, 6(1), 135-154. https://doi.org/10.33200/ijcer.567863.

Prabumulih, S. (2019). A Study of Listening Comprehension Problems Encountered by the Thord Semester Students at Stmik Prabumulih. Acitya: Journal of Teaching \& Education, 1(2), 100-109. https://media.neliti.com/media/publications/324608-a-a-study-of-listening-comprehension.

Putri, K. H., Ningsih, K., \& Refnaldi. (2018). The Effect of Authentic Listening Materials and Self-Regulation towards Students' Listening Ability at Tenth Grader of SMAN 1 Koto Sungai Sarak. Advances in Social Science, Education and Humanities Research, 301, 421-428. https: //doi.org/10.2991/icla.18.2019.70.

Putri, M., \& Sinaga, J. B. (2020). The Effect of Watching English Movie to Improve Students' Listening Skill. Anglo Saxon: Jurnal Ilmiah Program Studi Pendidikan Bahasa Inggris, 11(1), 110-117. https://doi.org/10.33373/as.v11i1.2449.

Rahmadani, H. (2018). The Effect of Video Blog towards Students' Listening Comprehension Skill. Advances in Social Science, Education and Humanities Research, 300, 1-8. https: //repository.unja.ac.id/4939/.

Rasmitadila, R., Aliyyah, R. R., Rachmadtullah, R., Samsudin, A., Syaodih, E., Nurtanto, M., \& Tambunan, A. R. S. (2020). The Perceptions of Primary School Teachers of Online Learning during the Covid-19 Pandemic Period: A Case Study in Indonesia. Journal of Ethnic and Cultural Studies, 7(2), 90. https://doi.org/10.29333/ejecs/388.

Rizkan, A. M., Mukhaiyar, \& Refnaldi. (2020). The Effect of Using Youtube as a Teaching Media on The Students' Listening Skill. Advances in Social Science, Education and Humanities Research, 301, 286291. https://doi.org/10.2991/icla-18.2019.48.

Shafwati, D., Sholihah, L., Prakoso, G. H., \& Riyantika, F. (2021). The Use of YouTube Video toward Students' Listening Ability. In ICOPE 2020: Proceedings of the 2nd International Conference on Progressive Education, ICOPE 2020, 16-17 October 2020, Universitas Lampung, Bandar Lampung, Indonesia. https://doi.org/10.4108/eai.16-10-2020.2305198.

Sutrisno, A. D. (2020). The Effect of English Conversation Videos on Students' Listening Skill. Ethical Lingua, 7(2), 389-394. https://doi.org/10.30605/25409190.196.

Vandergrift, L. (1999). Facilitating Second Language Listening Comprehension: Acquiring Successful Strategies. ELT Journal, 53(3), 168-176. https://academic.oup.com/eltj/articleabstract/53/3/168/2924470.

Yacoob, Z., \& Saad, N. H. M. (2020). Acceptance of Youtube as a Learning Platform during the Covid-19 Pandemic: The Moderating Effect of Subscription Status. TEM Journal, 9(4), 1732-1739. https: //doi.org/10.18421/TEM94-54.

Zaharah, Kirilova, G. I., \& Windarti, A. (2020). Impact of Corona Virus Outbreak towards Teaching and Learning Activities in Indonesia. Salam: Jurnal Sosial dan Budaya Syar'i, 7(3), 269-282. http://doi.org/10.15408/sjsbs.v7i3.15104. 